\title{
Lethal photosensitization of wound-associated microbes using indocyanine green and near-infrared light Ghada S Omar ${ }^{1,2}$, Michael Wilson*1 and Sean P Nair ${ }^{1}$
}

Address: ${ }^{1}$ Division of Microbial Diseases, UCL Eastman Dental Institute, University College London, 256 Gray's Inn Road, London WC1X 8LD, UK and ${ }^{2}$ Department of Surgery, Faculty of Physical Therapy, Cairo University, Cairo, Egypt

Email: Ghada S Omar - g.omar@eastman.ucl.ac.uk; Michael Wilson* - m.wilson@eastman.ucl.ac.uk; Sean P Nair - s.nair@eastman.ucl.ac.uk

* Corresponding author

Published: I July 2008

BMC Microbiology 2008, 8:1II doi:10.1 |86/I47I-2180-8-III
Received: 3 November 2007

Accepted: I July 2008

This article is available from: http://www.biomedcentral.com/I47I-2I80/8/III

(C) 2008 Omar et al; licensee BioMed Central Ltd.

This is an Open Access article distributed under the terms of the Creative Commons Attribution License (http://creativecommons.org/licenses/by/2.0), which permits unrestricted use, distribution, and reproduction in any medium, provided the original work is properly cited.

\begin{abstract}
Background: The increase in resistance to antibiotics among disease-causing bacteria necessitates the development of alternative antimicrobial approaches such as the use of light-activated antimicrobial agents (LAAAs). Light of an appropriate wavelength activates the LAAA to produce cytotoxic species which can then cause bacterial cell death via loss of membrane integrity, lipid peroxidation, the inactivation of essential enzymes, and/or exertion of mutagenic effects due to DNA modification. In this study, the effect of the LAAA indocyanine green excited with high or low intensity light $(808 \mathrm{~nm})$ from a near-infrared laser (NIR) on the viability of Staphylococcus aureus, Streptococcus pyogenes and Pseudomonas aeruginosa was investigated.

Results: All species were susceptible to killing by the LAAA, the bactericidal effect being dependent on both the concentration of indocyanine green and the light dose. Indocyanine green photosensitization using both high $(1.37 \mathrm{~W} \mathrm{~cm}-2)$ and low $\left(0.048 \mathrm{~W} \mathrm{~cm}^{-2}\right)$ intensity NIR laser light was able to achieve reductions of $5.6 \log _{10}(>99.99 \%)$ and $6.8 \log _{10}(>99.99 \%)$ in the viable counts of Staph. aureus and Strep. pyogenes (using starting concentrations of $10^{6}-10^{7} \mathrm{CFU} \mathrm{ml}^{-1}$ ). Kills of

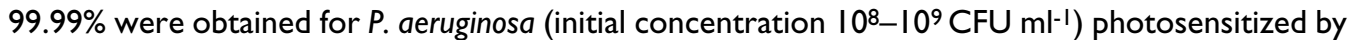
the high intensity light $\left(1.37 \mathrm{~W} \mathrm{~cm}^{-2}\right)$; while a kill of $80 \%$ was achieved using low intensity irradiation $\left(0.07 \mathrm{~W} \mathrm{~cm}^{-2}\right)$. The effects of L-tryptophan (a singlet oxygen scavenger) and deuterium oxide (as an enhancer of the life span of singlet oxygen) on the survival of Staph. aureus was also studied. Ltryptophan reduced the proportion of Staph. aureus killed; whereas deuterium oxide increased the proportion killed suggesting that singlet oxygen was involved in the killing of the bacteria.
\end{abstract}

Conclusion: These findings imply that indocyanine green in combination with light from a nearinfrared laser may be an effective means of eradicating bacteria from wounds and burns.

\section{Background}

Wound infections are an ongoing problem not only for patients but also for healthcare providers worldwide. Infected wounds are responsible for significant morbidity and mortality, and an increase in the duration and the cost of hospital stay [1-3]. The growing resistance to con- ventional antibiotics among organisms that infect wounds and burns makes such infections difficult to treat [4-6]. Therefore there is a drive to develop novel antimicrobial strategies to which pathogens will not easily develop resistance. 
One promising alternative is photodynamic therapy (PDT). Photodynamic therapy is the application of a nontoxic compound, termed a photosensitizer (PS) or lightactivated antimicrobial agent (LAAA), which can be activated by light of an appropriate wavelength to produce reactive oxygen species (ROS) (i.e. singlet oxygen and free radicals) which can then exert a microbicidal effect $[7,8]$. Light of the appropriate wavelength excites the PS molecule into a triplet state which reacts with either a substrate to produce radical ions which in turn react with oxygen to produce cytotoxic species such as superoxide and hydroxyl radicals (type I reaction), or reacts directly with molecular oxygen to produce singlet oxygen $\left({ }^{1} \mathrm{O}_{2}\right)$ (type II reaction). PDT has a number of advantages over conventional antibiotics. Firstly, as the mechanism of killing is non-specific, with reactive oxygen species causing damage to many bacterial components, resistance is unlikely to develop from repeated use $[9,10]$. Secondly, both the PS and the light are applied locally to the target tissue; therefore reducing the risk of adverse systemic effects [11]. Cutaneous wound infections are particularly appropriate for treatment by PDT due to their easy accessibility to both a topical PS and light. The organisms most frequently responsible for infections of wounds and burns are Streptococcus pyogenes, staphylococci, such as methicillin-resistant Staphylococcus aureus (MRSA), and the Gram-negative bacterium Pseudomonas aeruginosa [1]. Staphylococcus aureus is a common wound-infecting organism which results in delayed epithelial closure of the wound, possibly due to its interaction with fibronectin and inhibition of keratinocyte migration [12]. The eradication of woundinfecting bacteria using lethal photosensitization has been reported in the literature, e.g. Staph. aureus [13-15], P. aeruginosa [16-19], Strep. pyogenes [20].

In this study we have investigated whether common wound-associated organisms are sensitive to lethal photosensitization using the dye indocyanine green (ICG) coupled with light from a near-infrared (NIR) laser emitting at $808 \mathrm{~nm}$. This combination of PS and light source has a number of desirable characteristics over those described in the literature [13-20]. NIR laser light has a greater capacity to penetrate tissues than light of lower wavelengths whilst ICG is a NIR-absorbing water-soluble tricarbocyanine dye, which has been approved by the United States Food and Drug Administration (US FDA) for medical diagnostic studies. ICG has a very low toxicity and a high absorption at wavelengths around $800 \mathrm{~nm}$. Recently, PDT with ICG has been used to treat tumors $[21,22]$. However it has, as yet, not been used for the PDT of infections with the exception of its topical use for the treatment of acne vulgaris [23-25].

\section{Methods \\ Bacteria}

Two Gram-positive organisms were used in this study; Staph. aureus strain 8325-4 and Strep. pyogenes strain 12202. In addition, the Gram-negative bacterium Pseudomonas aeruginosa strain PA01 was used. Gram-positive bacteria were maintained by weekly subculture on blood agar base (Oxoid Ltd, UK) supplemented with 5\% horse blood whereas $P$. aeruginosa was subcultured on nutrient agar (Oxoid). Staph. aureus and P. aeruginosa were grown aerobically in nutrient broth (Oxoid) with shaking at $37^{\circ} \mathrm{C}$ for $16 \mathrm{~h}$. Strep. pyogenes was grown in brain heart infusion broth (Oxoid) for $16 \mathrm{~h}$ at $37^{\circ} \mathrm{C}$ in an atmosphere of $5 \% \mathrm{CO}_{2} / 95 \%$ air. Cells were then harvested by centrifugation and resuspended in phosphate buffered saline (PBS) to an optical density of 0.05 at $600 \mathrm{~nm}$ which corresponded to approximately $10^{6}-10^{7}$ colony forming units per $\mathrm{ml}(\mathrm{CFU} \mathrm{ml}-1)$ for the Gram-positive bacteria and $10^{8}-10^{9} \mathrm{CFU} \mathrm{ml}{ }^{-1}$ for $P$. aeruginosa.

\section{Photosensitizer}

4,5-benzoindotricarbocyanine (Indocyanine green) $\mathrm{C}_{43} \mathrm{H}_{47} \mathrm{~N}_{2} \mathrm{NaO}_{6} \mathrm{~S}_{2}$ is a negatively-charged polymethine dye and was obtained from Sigma-Aldrich-UK. Fresh stock solutions were prepared immediately prior to each experiment in either PBS or sterile distilled water $\left(\mathrm{H}_{2} \mathrm{O}\right)$ or deuterium oxide $\left(\mathrm{D}_{2} \mathrm{O}\right)$ and kept in the dark.

\section{Laser light}

A $500 \mathrm{~mW}$ Gallium-aluminum-arsenide (Ga-Al-As) NIRLaser (Thor International Ltd - UK) emitting light with a wavelength of $808 \pm 5 \mathrm{~nm}$ was used for irradiation. For experimental purposes, the distance of the laser probe to the plate surface was adjusted to give fluence rates of 1.37, 0.07 or $0.048 \mathrm{~W} \mathrm{~cm}^{-2}$ with an actual power output of 470 , 225 and $150 \mathrm{~mW}$ respectively.

\section{Effect of photosensitizer concentration on lethal photosensitization}

Aliquots $(50 \mu \mathrm{l})$ of a suspension of Staph. aureus, Strep. pyogenes (containing approximately $10^{6}-10^{7} \mathrm{CFU} \mathrm{ml} \mathrm{m}^{-1}$ ) or $P$. aeruginosa $\left(10^{8}-10^{9} \mathrm{CFU} \mathrm{ml}{ }^{-1}\right)$ in sterile PBS were transferred into a 96-well plate and an equal volume of ICG in PBS was added to each well to give final concentrations ranging from $25 \mu \mathrm{g} \mathrm{ml}^{-1}$ to $250 \mu \mathrm{g} \mathrm{ml}^{-1}$. After addition of the ICG, the wells were left in the dark for 10 or 30 minutes (pre-irradiation time) and then exposed to a measured dose of high intensity laser light at a fluence rate of $1.37 \mathrm{~W} \mathrm{~cm}^{-2}$. In this system, an exposure of 5 minutes corresponded to a light dose of $411 \mathrm{~J} \mathrm{~cm}^{-2}$. Each experimental condition was tested in at least triplicate and each experiment was carried out on at least two occasions. The conditions tested were; 1) controls which contained neither ICG nor received irradiation (L- S-), 2) incubation with ICG in the dark (L- S+), 3) irradiation in the absence of 
ICG (L+ S-) and 4) the test which was irradiated in the presence of ICG $(\mathrm{L}+\mathrm{S}+)$.

To enumerate the surviving bacteria, serial 10-fold dilutions were plated in duplicate either on blood agar (Staph. aureus and Strep. pyogenes) or nutrient agar (P. aeruginosa).

\section{Effect of low intensity laser light}

To avoid any heating effect that may occur during high intensity irradiation, the experiments were repeated using a laser power output of $150 \mathrm{~mW}$ to irradiate the samples at a low fluence rate of $0.048 \mathrm{~W} \mathrm{~cm}^{-2}$. Aliquots $(50 \mu \mathrm{l})$ of a suspension of Staph. aureus or Strep. pyogenes (containing

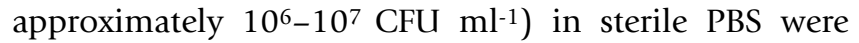
transferred into a 96-well plate and an equal volume of ICG in PBS was added to each well to give final concentration of $25 \mu \mathrm{g} \mathrm{ml}^{-1}$. After addition of the ICG, the wells were exposed to a measured dose of low intensity laser light for 15 or 30 minutes corresponding to light doses of 43 and $86 \mathrm{~J} \mathrm{~cm}^{-2}$ respectively. Similar experiments were performed with $P$. aeruginosa except that the concentration of ICG was $200 \mu \mathrm{g} \mathrm{ml}^{-1}$ and using a laser power output of $225 \mathrm{~mW}$ with a fluence rate of $0.07 \mathrm{~W} \mathrm{~cm}^{-2}$ for 35 minutes which corresponded to a light dose of $147 \mathrm{~J} \mathrm{~cm}^{-2}$.

\section{Effect of laser light dose}

The effect of laser light dose on bacterial killing was investigated by varying the exposure time whilst the distance from the light source remained constant. The bacterial suspensions were prepared as described above. A photosensitizer concentration of $25 \mu \mathrm{g} \mathrm{ml}^{-1}$ was used for photosensitizing the Gram-positive organisms while $200 \mu \mathrm{g} \mathrm{ml}^{-}$ ${ }^{1}$ was used for $P$. aeruginosa. Survival was determined after 1,3 , and 5 minutes irradiation at a high fluence rate of $1.37 \mathrm{~W} \mathrm{~cm}^{-2}$ which corresponded to energy doses of 28,85 and $141 \mathrm{~J}$ and energy densities of 82, 247 and $411 \mathrm{~J} \mathrm{~cm}^{-2}$ respectively.

\section{Effect of serum on the lethal photosensitization of Staph. aureus}

In order to investigate the lethal photosensitization of Staph. aureus in an environment similar to that which would exist in a wound, lethal photosensitization experiments were performed in the presence of $50 \%$ horse serum (HS). Staph. aureus was suspended in HS ( $10^{7} \mathrm{CFU}$ $\mathrm{ml}^{-1}$ ) and ICG (in PBS) added at concentrations of 25 or $200 \mu \mathrm{g} \mathrm{ml}^{-1}$ (bacteria were not washed after incubation with serum). After addition of ICG, samples of $100 \mu \mathrm{l}$ were irradiated at a fluence rate of $1.37 \mathrm{~W} \mathrm{~cm}^{-2}$ and light dose of $411 \mathrm{~J} \mathrm{~cm}^{-2}$.

\section{Effect of an enhancer of singlet oxygen life span on lethal photosensitization}

To determine if singlet oxygen was involved in the lethal photosensitization process, $\mathrm{D}_{2} \mathrm{O}$ (Sigma-Aldrich. UK) was used to extend the life span of any singlet oxygen generated by exposure of ICG to laser light. Staph. aureus was suspended in $\mathrm{D}_{2} \mathrm{O}$ or $\mathrm{H}_{2} \mathrm{O}\left(\sim 2 \times 10^{7} \mathrm{CFU} \mathrm{ml} \mathrm{ml}^{-1}\right)$ and ICG added to give a final concentration of $25 \mu \mathrm{g} \mathrm{ml}^{-1}$. Samples of $100 \mu \mathrm{l}$ in triplicate wells were exposed to laser light for 1 minute at a fluence rate of $1.37 \mathrm{~W} \mathrm{~cm}^{-2}$. Control wells were also prepared and either were not exposed to light but received ICG or did not receive ICG and were not exposed to light or did not receive ICG and were exposed to light.

\section{Effect of a free-radical and singlet oxygen scavenger on lethal photosensitization}

Staph. aureus was suspended in PBS $\left(\sim 2 \times 10^{7} \mathrm{CFU} \mathrm{ml} \mathrm{ml}^{-1}\right)$ or different concentrations of L-tryptophan $(10 \mu \mathrm{M}-10$ $\mathrm{mM}$ ) dissolved in PBS and incubated at $37^{\circ} \mathrm{C}$ for $1 \mathrm{~h}$ to detect any bactericidal activity of the scavenger itself. No bactericidal effect of the scavenger alone was detected. Samples of $100 \mu \mathrm{l}$ in triplicate wells containing Staph. aureus and $25 \mu \mathrm{g} \mathrm{ml}^{-1} \mathrm{ICG}\left(\mathrm{L}+\mathrm{S}+\right.$ ) in $\mathrm{H}_{2} \mathrm{O}$ (control) or the scavenger at a concentration of $10 \mathrm{mM}$ were exposed to laser light for 1 minute at a fluence rate of $1.37 \mathrm{~W} \mathrm{~cm}-2$. Control wells containing Staph. aureus and $10 \mathrm{mM}$ L-tryptophan were also prepared and either did not receive ICG and were not exposed to light (L-S-) or were not exposed to light but received ICG (L-S+) or did not receive ICG and were exposed to light (L+S-).

\section{Measurement of bacterial suspension temperature during lethal photosensitization and the effect of these temperatures on the viability of Staph. aureus and P. aeruginosa}

$100 \mu \mathrm{L}$ of the bacterial suspension, with final concentrations of 25,100 or $200 \mu \mathrm{g} \mathrm{ml}^{-1} \mathrm{ICG}_{\text {, were exposed to a }}$ measured dose of high intensity laser light for 1, 3 or 5 minutes $(\mathrm{L}+\mathrm{S}+)$ to determine the temperature elevation during lethal photosensitization. Three additional wells contained the microbial suspension plus PBS instead of the photosensitizer were exposed to the same light doses to determine the rise of temperature in the absence of ICG $(\mathrm{L}+\mathrm{S}-)$. The temperatures of the $\mathrm{L}+\mathrm{S}-$ and $\mathrm{L}+\mathrm{S}+$ aliquots were recorded immediately before and after irradiation using an immersion thermocouple probe connected to a Fluke 179 digital multimeter (Fluke. USA). The experiments were carried out in triplicate.

Aliquots of Staph. aureus either in sterile PBS or in HS

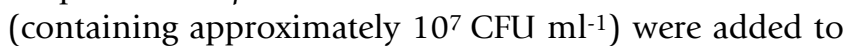
an equal volume of ICG to give a final concentration of 25 or $200 \mu \mathrm{g} \mathrm{ml}-1$, whereas $P$. aeruginosa suspension in PBS was added to ICG to give a final concentration of $200 \mu \mathrm{g}$ $\mathrm{ml}^{-1}$. Controls were prepared by adding an equal volume of PBS instead of ICG. The Staph. aureus suspensions were incubated either at $40^{\circ} \mathrm{C}$ (suspension in PBS) or $50^{\circ} \mathrm{C}$ (suspension in 50\% HS) whereas $P$. aeruginosa was incu- 
bated at $50^{\circ} \mathrm{C}$. All aliquots were incubated for 10 minutes in the dark. The survivors were enumerated by viable counting.

\section{Statistics}

All experiments were performed twice and at least in triplicate except for lethal photosensitization experiments in horse serum with $25 \mu \mathrm{g} \mathrm{ml}^{-1}$ which were performed twice but in duplicate. Values are expressed as means \pm standard deviation. Comparisons between means of groups were analyzed using the Mann-Whitney $U$ test. $P=0.05$ was considered statistically significant.

\section{Results}

Indocyanine green is an effective photosensitizer of wound-infecting organisms

When Staph. aureus was treated with different concentrations of ICG and exposed to $411 \mathrm{~J} \mathrm{~cm}^{-2}$ of high intensity NIR light a significant reduction in the viable count was achieved even with the minimum concentration of ICG used. For instance, when $25 \mu \mathrm{g} \mathrm{ml}^{-1}$ of ICG was used there was a significant $(P<0.01) 5.56 \log _{10}$ reduction in the viable count of the suspension which contained $2.55 \times 10^{7}$ CFU ml-1 corresponds to $99.99 \%$ efficacy. Suspensions of Staph. aureus treated with ICG but not irradiated (L- S+) showed a small $\left(0.5 \log _{10}\right)$ but significant $(P<0.05)$ reduction in the viable count (Figure 1).

When Strep. pyogenes was treated with different concentrations of ICG and exposed to $411 \mathrm{~J} \mathrm{~cm}^{-2}$ of NIR light, a sig-

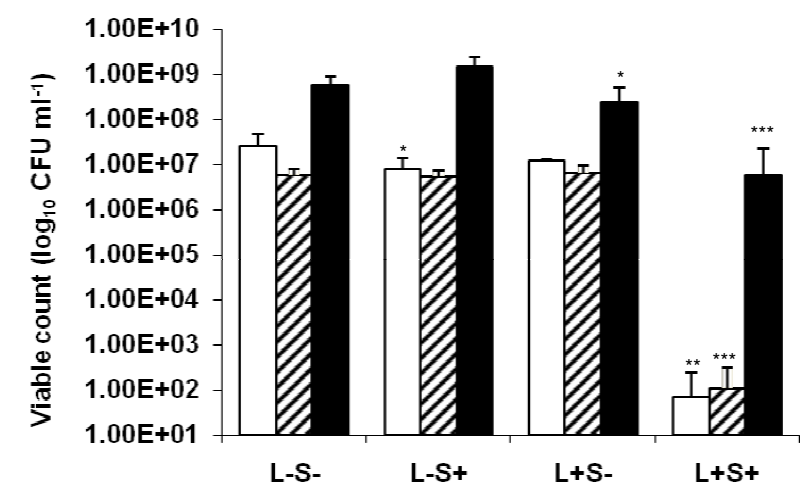

Figure I

High intensity lethal photosensitization of Staph. aureus $\square$ and Strep. pyogenes with $25 \mu \mathrm{g} \mathrm{ml}-1$ ICG or P. aeruginosa with $200 \mu \mathrm{g} \mathrm{ml} \mathrm{m}^{-1}$ ICG. An equal volume of either $50 \mu \mathrm{g} \mathrm{m} \mathrm{l}^{-1}$ (in the case of Staph. aureus and Strep. pyogenes) or $400 \mu \mathrm{g}$ $\mathrm{ml}^{-1}$ (in the case of $P$. aeruginosa) ICG (L-S+ and $\mathrm{L}+\mathrm{S}+$ ) or PBS (L-S- and L+S-) was added to each bacterial suspension, samples were left for 10 minutes in the dark and then irradiated at a fluence rate of $1.37 \mathrm{~W} \mathrm{~cm}^{-2}$ with a light dose of $41 \mathrm{I} \mathrm{J} \mathrm{cm}-$ 2 from a NIR $808 \mathrm{~nm}$ laser ( $(+S-$ and $L+S+$ ) or kept in the dark (L-S+ and L-S-). nificant $(P<0.001)$ reduction in the viable count was achieved even with the lowest concentration of ICG. Treatment with $25 \mu \mathrm{g} \mathrm{ml}^{-1}$ of ICG gave approximately a $4.7 \log _{10}(99.99 \%)$ reduction in the viable count. This

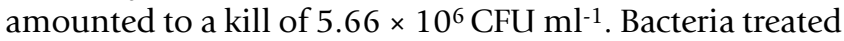
with ICG but not irradiated (L- S+), or those not treated with ICG but irradiated with NIR light did not show a significant reduction in viability (Figure 1).

When $P$. aeruginosa was treated with ICG, the concentration used to obtain a significant kill with the Gram-positive bacteria above was not sufficient to achieve killing upon irradiation. However, increasing the concentration of ICG to $200 \mu \mathrm{g} \mathrm{ml}^{-1}$ gave a significant $(P<0.001) 2 \log _{10}$ $(99.1 \%)$ reduction in the viable count on irradiation. This equated to killing of approximately $5.99 \times 10^{8} \mathrm{CFU} \mathrm{ml}-1$. Interestingly, irradiation of $P$. aeruginos $a$ with NIR light in the absence of ICG resulted in a significant $(P<0.05)$ reduction in the viability of this organism (approximately $0.4 \log _{10}$ reduction) albeit not as great as that achieved in the presence of ICG (Figure 1).

\section{The effect of various dye concentrations}

The bactericidal effect in all species was dependent on the ICG concentration. Figure 2 shows the $\log _{10}$ unit reduction in the viable count in the three micro-organisms when treated with different concentration of the PS and using a light dose of $411 \mathrm{~J} \mathrm{~cm}^{-2}$ at a fluence rate of $1.37 \mathrm{~W}$ $\mathrm{cm}^{-2}$. The minimum effective concentration for killing the

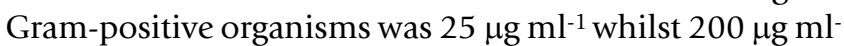
${ }^{1}$ was needed to kill $P$. aeruginosa.

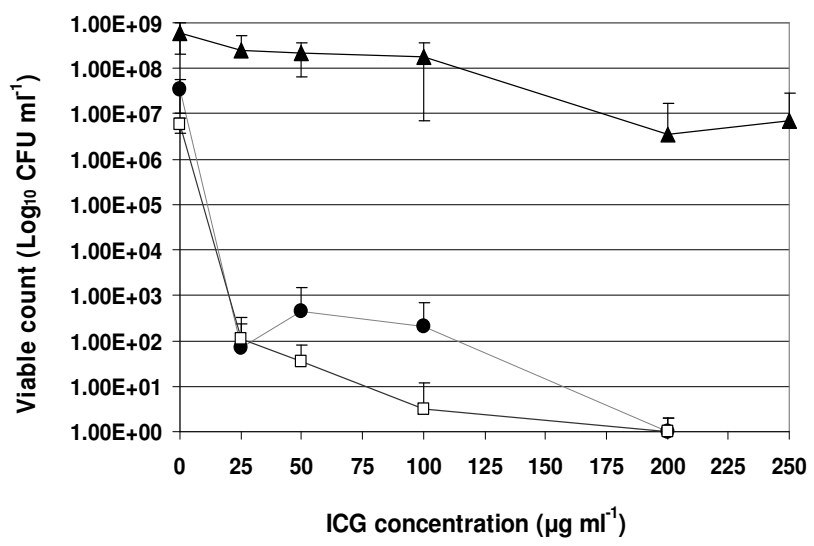

\section{Figure 2}

Lethal photosensitization of Staph. aureus $\bullet$, Strep. pyogenes $\square$ with 25,50, 100 and $200 \mu \mathrm{g} \mathrm{ml} \mathrm{I}^{-1}$ ICG, and P. aeruginosa $\boldsymbol{\Delta}$ with 25,50, 100, 200 and $250 \mu \mathrm{g} \mathrm{ml}^{-1}$ ICG. An equal volume of the appropriate ICG concentration $(L+S+)$ was added to each bacterial suspension, samples were left for 10 minutes in the dark and then irradiated at a fluence rate of $1.37 \mathrm{~W}$ $\mathrm{cm}^{-2}$ with light dose of $4 \mathrm{II} \mathrm{J} \mathrm{cm}-2$ from a NIR $808 \mathrm{~nm}$ laser. 


\section{The effect of low intensity light}

Irradiation of Staph. aureus in the presence of ICG for 15 or 30 minutes with a low fluence rate of $0.048 \mathrm{~W} \mathrm{~cm}^{-2}$ achieved a significant $(P<0.001)$ reduction of 3.8 and 4.3 $\log _{10}$ in the viable count respectively (Figure 3A). Using the same conditions, irradiation of Strep. pyogenes resulted in significant $(P<0.001)$ reductions of 3.7 and $5.4 \log _{10}$ in the viable count respectively (Figure $3 \mathrm{~A}$ ). For both gram positive-bacteria, kills amounting to 99.98 and $99.99 \%$ reductions in the viable count were achieved depending on the irradiation time. In the case of $P$. aeruginosa, a significant $(P=0.001)$ reduction of $0.7 \log _{10}(80 \%)$ in the viable count was achieved in the presence of $200 \mu \mathrm{g} \mathrm{ml}^{-1}$ ICG which was irradiated for 35 minutes at a fluence rate of $0.07 \mathrm{~W} \mathrm{~cm}^{-2}$, corresponding to a light dose of $147 \mathrm{~J} \mathrm{~cm}^{-}$ 2 .

Amongst the three bacteria, only irradiation of $P$. aeruginos $a$ with NIR light in the absence of ICG resulted in a sig-

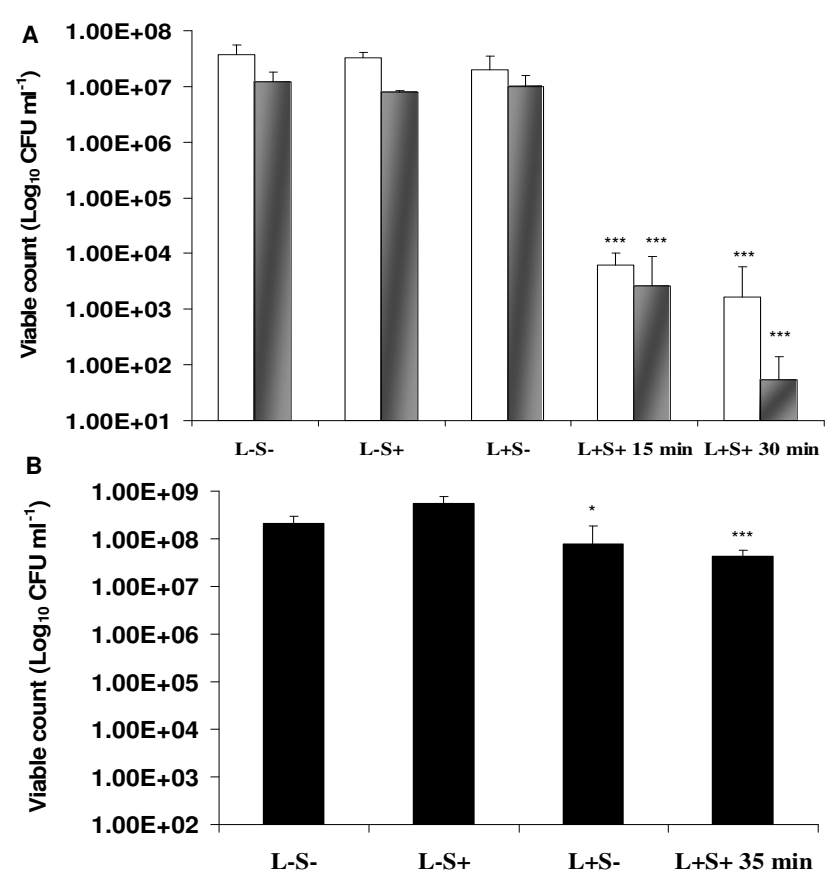

Figure 3

(A) Lethal photosensitization of Staph. aureus $\square$ and Strep. pyogenes $\square$ using a final concentration of $25 \mu \mathrm{g} \mathrm{ml^{-1 }}$ ICG. Samples were left for 10 minutes in the dark and then irradiated using a fluence rate of $0.048 \mathrm{~W} \mathrm{~cm}-2$ for 15 and 30 minutes, corresponding to light doses of $43 \& 86 \mathrm{~J} \mathrm{~cm}^{-2}$ respectively. (B) Lethal photosensitization of $P$. aeruginosa using a final concentration of $200 \mu \mathrm{g} \mathrm{ml} \mathrm{m}^{-1}$ ICG. Samples were left for 10 minutes in the dark and then irradiated using a fluence rate of $0.07 \mathrm{~W} \mathrm{~cm}^{-2}$ for 35 minutes, corresponding to light dose of $147 \mathrm{~J} \mathrm{~cm}^{-2}$. L-S- and L+S- were kept in the dark. nificant $(P<0.05) 0.44 \log _{10}(64 \%)$ reduction in the viability of this organism (Figure $3 \mathrm{~B}$ ).

\section{The effect of light dose}

During high intensity irradiation, the bactericidal effect was dependent on the light dose delivered. Significant $(P$ $<0.01$ ) reductions of 2.54 (99.7\%), 3.36 (99.94\%), and $5.15 \log _{10}(99.99 \%)$ in the viable count of Staph. aureus were achieved using exposure times of 1, 3 and 5 minutes respectively. Significant $(P<0.001) \log _{10}$ reductions in the viable count of Strep. pyogenes were 3.94 (99.99\%), 6.82 $(99.99 \%)$ and $6.13(99.99 \%)$ using light doses of 1, 3 and 5 minutes respectively. In the case of $P$. aeruginosa, lethal photosensitization using exposure times of 1,3 and 5 minutes achieved significant $(P<0.001)$ kills of $1.35,1.75$ and $4.74 \log _{10}$ corresponding to $95.5,98.2$ and $99.99 \%$ reductions in the viable count respectively. However, in the absence of ICG, irradiation of $P$. aeruginosa also resulted in significant kills, with exposure times of 1,3 and 5 minutes achieving $\log _{10}$ reduction in the viable count of $0.66(78.2 \%), 0.85(85.93 \%)$ and $1.36(95.65 \%)$ respectively (Figure 4 ).

\section{Lethal photosensitization of Staph. aureus in the presence of serum}

In the presence of HS, lethal photosensitization of Staph. aureus using a high fluence rate was significantly inhibited (Figure 5). Lethal photosensitization using $25 \mu \mathrm{g} \mathrm{ml}^{-1} \mathrm{ICG}$ and an irradiation time of 5 minutes in $50 \%$ HS gave a significant $(P<0.05) 0.3 \log _{10}$ reduction in the viable count

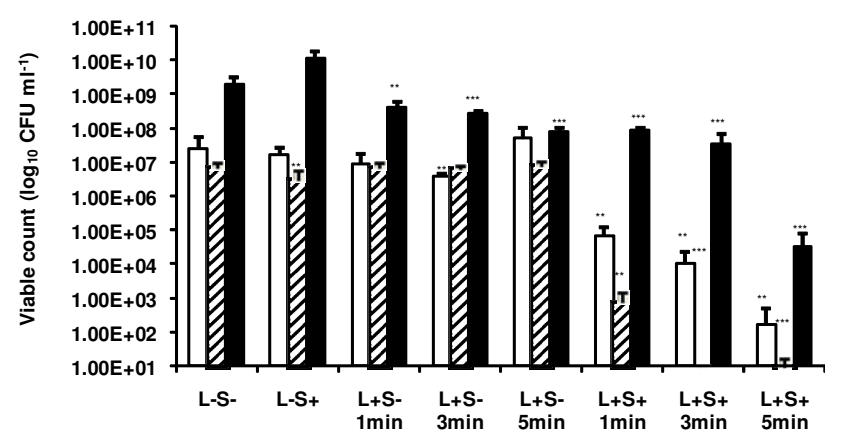

Figure 4

High intensity lethal photosensitization of Staph. aureus $\square$, Strep. pyogenes with $25 \mu \mathrm{g} \mathrm{ml}^{-1} \mathrm{ICG}$ and $P$. aeruginosa with $200 \mu \mathrm{g} \mathrm{ml} \mathrm{m}^{-1} \mathrm{ICG}$. An equal volume of either $50 \mu \mathrm{g} \mathrm{ml}$ (in the case of Staph. aureus and Strep. pyogenes) or $400 \mu \mathrm{g}$ $\mathrm{ml}^{-1}$ (in the case of $P$. aeruginosa) ICG (L-S+ and L+S+) or PBS (L-S- and L+S-) was added to each bacterial suspension. Samples were left in the dark for 30 minutes and then $(L+S-$ and $\mathrm{L}+\mathrm{S}+$ ) irradiated at a fluence rate of $\mathrm{I} .37 \mathrm{~W} \mathrm{~cm} \mathrm{~cm}^{-2}$ for I, 3 or 5 minutes with light from a NIR $808 \mathrm{~nm}$ laser, corresponding to light doses of 82,247 , or $4 \mathrm{II} \mathrm{J} \mathrm{cm}^{-2}$ respectively. Samples L-S+ and L-S- were kept in the dark. 


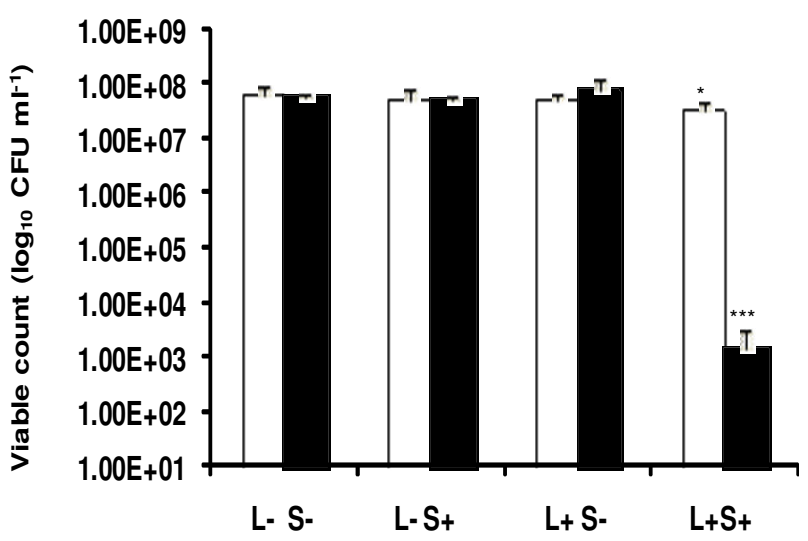

Figure 5

Lethal photosensitization of Staph. aureus in $50 \%$ horse serum (HS) using $25 \square$ or $200 \square \mu \mathrm{ml}^{-1}$ ICG. An equal volume of either 50 or $400 \mu \mathrm{g} \mathrm{m}^{-1}$ ICG (L-S+ and L+S+) or PBS (L-S- and L+S-) was added to Staph. aureus suspensions in HS and samples were left for 10 minutes in the dark and then irradiated at a fluence rate of $1.37 \mathrm{~W} \mathrm{~cm} \mathrm{~cm}^{-2}$ and a light dose of $41 \mathrm{I} \mathrm{cm}^{-2}$ using a NIR $808 \mathrm{~nm}$ laser ( $L+S$ - and $L+S+$ ) or kept in the dark (L-S+ and L-S-).

compared to a $5 \log _{10}$ reduction in the absence of serum. However, increasing the concentration of ICG to $200 \mu \mathrm{g}$ $\mathrm{ml}^{-1}$ and exposure to the same light dose achieved a 4.61 $\log _{10}$ reduction in the viable count in the presence of serum $(P<0.001)$.

\section{Lethal photosensitization of Staph. aureus in the} presence of a singlet oxygen scavenger or enhancer

The singlet oxygen scavenger, L-tryptophan, significantly reduced the lethal photosensitization of Staph. aureus $(P<$ $0.01)$. One $\log _{10}$ reduction in the number of Staph. aureus killed was found in the presence of L-tryptophan over that in the absence of this scavenger (Figure 6A). Conversely, $\mathrm{D}_{2} \mathrm{O}$ considerably enhanced the killing of Staph. aureus with a $1.62 \log _{10}$ greater reduction in viable counts compared to those achieved in the absence of $\mathrm{D}_{2} \mathrm{O}(P<0.01)$ (Figure 6B).

\section{Temperature elevation during lethal photosensitization and its effect on the viability of bacteria}

The temperature of the bacterial suspensions was elevated during high intensity lethal photosensitization with ICG. The rises in temperature depended on the light dose delivered and the concentration of the photosensitizer. The temperature of the bacterial suspensions increased from $22^{\circ} \mathrm{C}$ to $37^{\circ} \mathrm{C}$ during irradiation with the highest light dose and a dye concentration of $25 \mu \mathrm{g} \mathrm{ml}^{-1}$, whereas using $200 \mu \mathrm{g} \mathrm{ml}^{-1}$ of ICG in either PBS or $50 \% \mathrm{HS}$, the temperature increased to a maximum of $47^{\circ} \mathrm{C}$. No change in the viable count was observed after incubation of Staph.

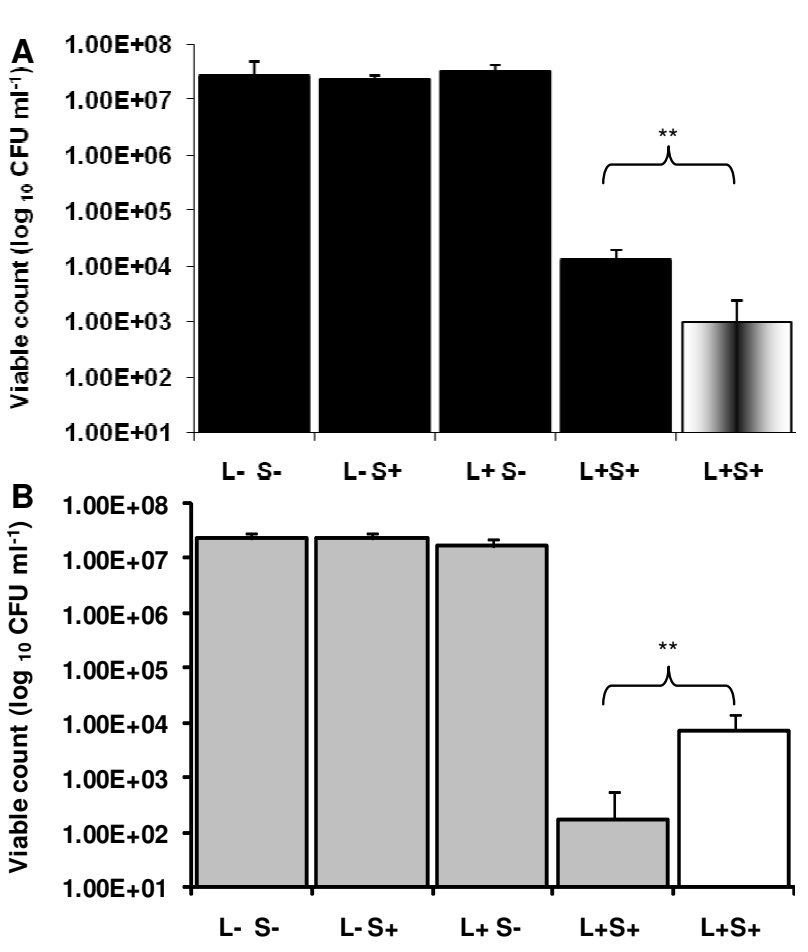

\section{Figure 6}

High intensity lethal photosensitization of Staph. aureus (A) suspended in 10 mM L-tryptophan $\square$ or suspended in $\mathrm{H}_{2} \mathrm{O}$ and (B), suspended in $\mathrm{D}_{2} \mathrm{O} \square$ or suspended in $\mathrm{H}_{2} \mathrm{O} \square$. In this experiment an ICG concentration of $25 \mu \mathrm{g} \mathrm{ml} \mathrm{m}^{-1}$ was used and samples were pre-incubated in the dark for 10 minutes before being irradiated at a fluence rate of $1.37 \mathrm{~W} \mathrm{~cm}^{-2}$ and light dose of $82 \mathrm{~J} \mathrm{~cm}^{-2}$.

aureus suspended in PBS, in the absence or presence of 25 $\mu \mathrm{g} \mathrm{ml}^{-1} \mathrm{ICG}$, and incubated for 10 minutes at $40^{\circ} \mathrm{C}$ in the dark. Horse serum provided a protective effect for Staph. aureus, a slight increase or no change in the viable count was noted after Staph. aureus was suspended in PBS containing $50 \% \mathrm{HS}$ in the absence or presence of $200 \mu \mathrm{g} \mathrm{ml}^{-1}$ ICG and incubation for 10 minutes at $50^{\circ} \mathrm{C}$. A statistically non-significant reduction was observed in the viable count of $P$. aeruginosa suspended in PBS, in the absence or presence of $200 \mathrm{~g} \mathrm{~m} \mathrm{~m}^{-1} \mathrm{ICG}$, and incubated for $10 \mathrm{~min}$ utes at $50^{\circ} \mathrm{C}$. The viable count reduction was always less than $0.4 \log _{10}$ (data not shown).

\section{Discussion}

Indocyanine green is a water-soluble anionic photosensitizer which is widely used in medical diagnosis. It is approved by the US FDA for use in humans, in ophthalmology for retinal angiography as well as being used for diagnostic assessment of liver function and cardiac output and determining burn depth $[26,27]$. A number of in vitro 
and in vivo studies of the potential use of ICG-mediated PDT have been carried out. In vitro researches reported an inhibitory effect of photoactivated ICG on pancreatic cancer cells [28], colonic cancer cells [29], human (SKMEL 188) and mouse (S91) melanoma cells [30]. These studies suggested that ICG was a promising photosensitizer for clinical PDT but that further in vivo investigations were needed. Several authors have investigated ICG cyto-toxicity and photo-toxicity using in vitro, [31-34], in vivo, [35,36] and ex vivo models [37]. Some of these have reported phototoxicity in eukaryotic cells which was dependent on pre-irradiation time, ICG concentration, and light dose. Abels et al., 2000 reported that ICG phototoxicity depends on the pre-irradiation time [38]. After $1 \mathrm{~h}$ pre-irradiation time, no significant phototoxicity on HaCaT keratinocytes was detected using an ICG concentration as high as $50 \mu \mathrm{M}$ and light doses of $48 \mathrm{~J} / \mathrm{cm}^{2}$ (80 $\mathrm{mW} / \mathrm{cm}^{2}$ ). Phototoxicity of ICG at concentrations of 25 $\mu \mathrm{M}$ was detected after $4 \mathrm{~h}$ pre-irradiation while a concentration as low as $10 \mu \mathrm{M}$ was phototoxic after $24 \mathrm{~h}$ [38]. However, in the current study the pre-irradiation time was no more than 30 minutes which implies that keratinocyte phototoxicity would not be a problem under these conditions.

In humans, ICG-mediated PDT has been used in the treatment of acne vulgaris [23-25]. A recent pilot study was carried out by Tuchin et al, (2003) on the effects of ICG photodynamic and photothermolysis treatment on acne vulgaris. In this study, the authors used a very high concentration of ICG $(1.0 \mathrm{mg} / \mathrm{ml})$, a pre-irradiation time of 5 or 15 minutes and very high light dose and fluence rates of NIR laser-diode light (803 or $809 \mathrm{~nm}$ ). For soft acne treatment, the low intensity $\left(803 \mathrm{~nm}, 10-50 \mathrm{~mW} / \mathrm{cm}^{2}\right.$, 5-10 minutes) or the medium-intensity (809 $\mathrm{nm}$, $150-190 \mathrm{~mW} / \mathrm{cm}^{2}, 15$ minutes) protocols were used. Single and multiple (up to 8-9) treatments were studied. The individual acne lesions were photothermally treated at 18 $\mathrm{W} / \mathrm{cm}^{2}$ (803 $\mathrm{nm}, 0.5 \mathrm{~seconds}$ ) without skin surface cooling or at $200 \mathrm{~W} / \mathrm{cm}^{2}(809 \mathrm{~nm}, 0.5$ seconds) with cooling. As no adverse effects were reported, the investigators concluded that such high light intensities and ICG concentrations were safe for use in humans [23].

The purpose of this study was to investigate whether ICG in combination with light from a NIR laser is effective at killing common wound-infecting organisms and to determine the fluence rates needed to photosensitize woundinfecting organisms. The results of the study have shown that all three organisms tested are susceptible to lethal photosensitization using ICG as a photosensitizer in combination with $808 \mathrm{~nm}$ light using both high and low fluence rates. At high fluence rates the Gram-negative bacterium $P$. aeruginosa showed no resistance to lethal photosensitization with ICG in the presence of high con- centrations of the photosensitizer. However at the low fluence rate $P$. aerusginosa did show resistance to the lethal photosensitization process while the Gram-positive organisms (Staph. aureus and Strep. pyogenes) were not resistant. The lethal photosensitization of these woundinfecting organisms with ICG was dependent on the light dose and ICG concentration.

The differing susceptibilities of the Gram-negative and Gram-positive organisms to lethal photosensitization in this study are probably attributable to differences in cell wall structures. Gram-negative bacteria have an outer membrane that may reduce the uptake of reactive oxygen species by the bacterium [9]. In addition the presence of lipopolysaccharide (LPS) in the outer membrane of Gram-negative bacteria acts as a very effective permeability barrier to many of the molecules in the external environment and contributes to the development of drugresistance in these organisms [39]. In contrast, Gram-positive bacteria have a porous outer layer of peptidoglycan which is a less effective permeability barrier [40]. Gramnegative bacteria are known to be relatively impermeable to neutral or anionic drugs and ICG is an anionic dye [41].

Interestingly, both high and low intensity $808 \mathrm{~nm}$ light alone was able to exert a cidal effect against $P$. aeruginosa. This killing effect was not heat mediated as the temperature of the bacterial suspensions did not exceed $33^{\circ} \mathrm{C}$ during irradiation. This finding is supported by the results of a previous study in which irradiation of the organism with $1-80 \mathrm{~J} \mathrm{~cm}^{-2}$ laser light at a wavelength of $810 \mathrm{~nm}$ and using an irradiance rate of $0.03 \mathrm{~W} \mathrm{~cm}^{-2}$ resulted in a significant inhibition of bacterial growth [42]. A possible explanation for this observation is that $P$. aeruginosa has endogenous pigments (pyoverdin and pyocyanin) that may absorb the light and result in the production of bactericidal species [16]. The current data suggest that NIR laser light irradiation by itself would also inhibit growth of $P$. aeruginosa in infected wounds.

A prerequisite for successful antimicrobial PDT to treat wound infection is its efficiency in the presence of wound fluid. To more closely mimic the conditions likely to be experienced in vivo, we investigated the effect of serum on the lethal photosensitization of Staph. aureus. Horse serum reduced the effectiveness of lethal photosensitization with ICG possibly because serum proteins in the environment bind to the ICG thereby preventing its uptake by the organism [43] or else they may act as quenchers of the singlet oxygen produced thereby protecting the bacterial cells from their lethal effects [44]. However, increasing the concentration of ICG overcame the inhibitory effect of serum suggesting that killing of the organism may be achievable in vivo. Our findings were confirmed by the results of Lambrechts et al. which 
showed that albumin inhibited the photodynamic inactivation (PDI) of Staph. aureus and exerted a dose dependent protective effect against the PDI of the microorganism which was dependent on the albumin content of the suspending fluid [45].

To reveal something of the underlying mechanisms involved in killing of the wound-infecting organisms by ICG, lethal photosensitization experiments were carried out in the presence of an enhancer of ${ }^{1} \mathrm{O}_{2}$ life span $\left(\mathrm{D}_{2} \mathrm{O}\right)$ or a quencher of ${ }^{1} \mathrm{O}_{2}$ (L-tryptophan) [46]. The augmentation of Staph. aureus killing in the presence of $\mathrm{D}_{2} \mathrm{O}$ demonstrated that enhancement of the life span of ${ }^{1} \mathrm{O}_{2}$ increases the bactericidal effect thereby suggesting the involvement of this cytotoxic species in the lethal photosensitization process. Further evidence of the involvement of singlet oxygen is provided by the protective effect of the singlet oxygen scavenger, tryptophan.

However during the lethal photosensitization experiments at high fluence rate and the highest concentration of ICG $\left(200 \mu \mathrm{g} \mathrm{ml}^{-1}\right)$, the temperature of the bacterial suspensions increased to $47^{\circ} \mathrm{C}$, whereas at lower concentrations the temperature did not exceed $42^{\circ} \mathrm{C}$. According to the literature, temperatures of a few degrees above the physiological norm, i.e., $42-45^{\circ} \mathrm{C}$ can induce cell apoptosis. However, as normal tissues approach this temperature, intrinsic heat dissipation occurs (possibly due to augmented blood flow) so that temperatures up to $45^{\circ} \mathrm{C}$ could be tolerated by the tissues [47]. More prolonged heating can be associated with secondary necrosis of apoptotic cells, where the cells retained some of the features of apoptosis but had superimposed features of necrosis including membrane disintegration and swelling of cytoplasmic organelles. After a few days, apoptotic cells are phagocytosed by tissue mononuclear phagocytes. Temperatures greater than $45^{\circ} \mathrm{C}\left(45-48^{\circ} \mathrm{C}\right)$ cause prolonged necrosis, uniformly affecting all cells in tissue structure [48]. It also should be noted that heating has some synergic effect when applied together with PDT [49]; therefore more effective bacterial killing can be achieved. In clinical practice, providing an effective cooling system for the skin surface [50] or else the use of a pulsed laser may avoid tissue necrosis.

In order to ascertain whether this temperature rise was responsible for the kills achieved, the test organisms were exposed to a slightly higher temperature than that which occurred during lethal photosensitization and for longer periods of time. As exposure to these temperatures resulted in no, or only slight, reductions in bacterial viability, it can be concluded that the observed kills were attributable to the light-induced generation of singlet oxygen (and, possibly, free radicals) rather than to thermal effects. Even though the temperature of Staph. aureus sus- pensions containing $200 \mu \mathrm{g} \mathrm{ml}^{-1}$ ICG increased up to $47^{\circ} \mathrm{C}$, there was no significant reduction in the viable count of Staph. aureus in 50\% HS at a similar temperature $\left(50^{\circ} \mathrm{C}\right)$. It may be that protein molecules in the serum provide protection against the heating effect. This observation suggests that killing of Staph. aureus was more likely attributable to the products of lethal photosensitization. In addition, irradiating the bacteria with low fluence rates of 0.048 or $0.07 \mathrm{~W} \mathrm{~cm}^{-2}$ resulted in significant reduction in the viability of the three bacteria. These results support the hypothesis that the cytotoxic species produced from the photosensitization process are responsible for bacterial kill.

The notion of disinfecting burns and wounds using a noninvasive and localized strategy such as PDT with limited damage to the host tissue is well documented in the literature $[10,51,52]$. Lambrechts et al achieved 3.6 or 4.8 $\log _{10}$ units reduction in the viability of Staph. aureus using $635 \mathrm{~nm}$ light with a light dose of 0.6 or $1.5 \mathrm{~J} \mathrm{~cm}^{-2}$ and 1.56 $\mu \mathrm{M}$ 5-phenyl-10,15,20-tris( $\mathrm{N}$-methyl-4-pyridyl) porphyrin chloride (PTMPP) [10]. Taking into account the variation in experimental design, we achieved a $5.5 \log _{10}$ unit reduction in the viability of Staph. aureus using $25 \mu \mathrm{g} \mathrm{ml}^{-1}$ ICG $(32 \mu \mathrm{M})$ and a light dose of $411 \mathrm{~J} \mathrm{~cm}^{-2}$ from a coherent light source ( $808 \mathrm{~nm}$ ) which allows deeper tissue penetration than the light source $(635 \pm 15 \mathrm{~nm})$ used in the above mentioned study. In another study, Orenstein et al. used a mixture of deuteroporphyrin and hemin which successfully disinfected burns infected with Staph. aureus even in the dark without illumination [15]. In contrast, the ICG used in the current study had minimal dark toxicity against the organisms tested. ICG is a comparatively weak photosensitizer because the yields of the triplet state appear low compared with other photosensitizers used in PDT [29]. Nevertheless, the data obtained in this study have shown that significant kills of Staph. aureus and Strep. pyogenes can be achieved using a low concentration of the photosensitizer of $25 \mu \mathrm{g} \mathrm{ml}^{-1}$ and a low light dose of $43 \mathrm{~J}$ $\mathrm{cm}^{-2}$. The gram-negative organism, $P$. aeruginosa, appeared to be less susceptible as higher ICG concentrations and higher light doses were needed to achieve substantial kills. Interestingly, however, appreciable kills of the organism were attained by irradiation in the absence of the ICG. It is well established that humans can tolerate systemic ICG concentrations in the $\mathrm{mg} / \mathrm{ml}$ range i.e. 5 -fold greater than those used in this study.

The phototherapeutic window of many PSs effective against bacteria is $600-780 \mathrm{~nm}$ [53]. The most frequently studied PSs are activated by light wavelengths between 632.8-665 nm [54]. However, light of such wavelengths has limited tissue penetration compared to light with a wavelength of $808 \mathrm{~nm}$ [55] which we used to activate ICG in the present study. In fact, the depth of penetration dou- 
bles from $4 \mathrm{~mm}$ at $500-600 \mathrm{~nm}$ to $8 \mathrm{~mm}$ at $800 \mathrm{~nm}$ [56]. This may enable killing of bacteria within deeper wounds and burns. In addition, ICG is of very low toxicity and is rapidly excreted from the body so that any possible damage to host tissue would be limited.

\section{Conclusion}

In summary, the results of the present study suggest that indocyanine green in combination with near-infrared light is a promising candidate for the photodynamic therapy of burn and wound infections. Furthermore, the NIR laser light itself may be able to disinfect wounds contaminated with $P$. aeruginosa. Use of this approach would reduce the requirements for systemic antibiotics in the management of skin infections and thereby help to reduce the emergence of antibiotic resistance. Although the results of these in vitro studies are promising, in vivo studies are needed to ascertain whether appreciable bacterial kills can be obtained in a wound model.

\section{Abbreviations}

D2O: Deuterium Oxide; DNA: Diribonucleic acid; HS: Horse serum; ICG: Indocyanine green; LAAA: Light activated antimicrobial agent; NIR: Near Infra-red; PBS: Phosphate buffered saline; PDT: Photodynamic therapy; PS: Photosensitizer; ROS: Reactive oxygen species; US FDA: United State Food and Drug Administration.

\section{Authors' contributions}

GSO: conceived of the study, participated in the study design, carried out the microbiological studies, performed the statistical analysis and drafted the manuscript. MW: conceived of the study, participated in its design and coordination and helped to draft the manuscript. SPN: conceived of the study, participated in its design and coordination, provided technical support and helped to draft the manuscript. All authors read and approved the final manuscript.

\section{Acknowledgements}

This work has been supported by a studentship awarded by the Egyptian government to G. Omar.

\section{References}

I. Ansermino M, Hemsley $C$ : Intensive care management and control of infection. BMJ 2004, 329:220-223.

2. Healy B, Freedman A: Infections. BMJ 2006, 332:838-84I

3. Plowman R: The socioeconomic burden of hospital acquired infection. Euro Surveill 2000, 5:49-50.

4. Cuthbertson BH, Thompson M, Sherry A, Wright MM, Bellingan GJ: Antibiotic-treated infections in intensive care patients in the UK. Anaesthesia 2004, 59:885-890.

5. Finch R: Antibiotic resistance - from pathogen to disease surveillance. Clin Microbiol Infect 2002, 8:317-320.

6. Ogeer-Gyles JS, Mathews KA, Boerlin P: Nosocomial infections and antimicrobial resistance in critical care medicine. I Vet Emerg Crit Care 2006, 16:1-18.

7. Hamblin MR, O'Donnell DA, Murthy N, Rajagopalan K, Michaud N, Sherwood ME, Hasan T: Polycationic photosensitizer conjugates: effects of chain length and Gram classification on the photodynamic inactivation of bacteria. I Antimicrob Chemother 2002, 49:94I-95I.

8. Embleton ML, Nair SP, Heywood W, Menon DC, Cookson BD, Wilson $M$ : Development of a novel targeting system for lethal photosensitization of antibiotic-resistant strains of Staphylococcus aureus. Antimicrob Agents Chemother 2005, 49:3690-3696.

9. Jori G, Fabris C, Soncin M, Ferro S, Coppellotti O, Dei D, Fantetti L, Chiti G, Roncucci G: Photodynamic therapy in the treatment of microbial infections: basic principles and perspective applications. Lasers Surg Med 2006, 38:468-48I.

10. Lambrechts SA, Demidova TN, Aalders MC, Hasan T, Hamblin MR: Photodynamic therapy for Staphylococcus aureus infected burn wounds in mice. Photochem Photobiol Sci 2005, 4:503-509.

II. Hamblin MR, Hasan T: Photodynamic therapy: a new antimicrobial approach to infectious disease? Photochem Photobiol Sci 2004, 3:436-450.

12. Kintarak S, Nair SP, Speight PM, Whawell SA: A recombinant fragment of the fibronectin-binding protein of Staphylococcus aureus inhibits keratinocyte migration. Arch Dermatol Res 2004, 296:250-257.

13. Bisland SK, Chien C, Wilson BC, Burch S: Pre-clinical in vitro and in vivo studies to examine the potential use of photodynamic therapy in the treatment of osteomyelitis. Photochem Photobiol Sci 2006, 5:31-38

14. Wilson M, Pratten J: Lethal photosensitisation of Staphylococcus aureus in vitro: effect of growth phase, serum, and preirradiation time. Lasers Surg Med 1995, 16:272-276.

15. Orenstein A, Klein D, Kopolovic J, Winkler E, Malik Z, Keller N, Nitzan $Y$ : The use of porphyrins for eradication of Staphylococcus aureus in burn wound infections. FEMS Immunol Med Microbiol 1997, | 9:307-3|4.

16. Reszka KJ, Denning GM, Britigan BE: Photosensitized oxidation and inactivation of pyocyanin, a virulence factor of Pseudomonas aeruginosa. Photochem Photobiol 2006, 82:466-473.

17. Nitzan Y, Gutterman M, Malik Z, Ehrenberg B: Inactivation of gram-negative bacteria by photosensitized porphyrins. Photochem Photobiol 1992, 55:89-96.

18. Minnock A, Vernon DI, Schofield J, Griffiths J, Parish JH, Brown ST: Photoinactivation of bacteria. Use of a cationic water-soluble zinc phthalocyanine to photoinactivate both gram-negative and gram-positive bacteria. J Photochem Photobiol B 1996, 32: $159-164$.

19. Hamblin MR, Zahra T, Contag CH, McManus AT, Hasan T: Optical monitoring and treatment of potentially lethal wound infections in vivo. J Infect Dis 2003, I87:1717-1725.

20. Hope CK, Wilson M: Induction of lethal photosensitization in biofilms using a confocal scanning laser as the excitation source. J Antimicrob Chemother 2006, 57:1227-I230.

21. Saxena V, Sadoqi M, Shao J: Degradation kinetics of indocyanine green in aqueous solution. J Pharm Sci 2003, 92:2090-2097.

22. Saxena V, Sadoqi M, Shao J: Polymeric nanoparticulate delivery system for Indocyanine green: biodistribution in healthy mice. Int J Pharm 2006, 308:200-204.

23. Tuchin VV, Genina EA, Bashkatov AN, Simonenko GV, Odoevskaya OD, Altshuler GB: A pilot study of ICG laser therapy of acne vulgaris: photodynamic and photothermolysis treatment. Lasers Surg Med 2003, 33:296-310.

24. Genina EA, Bashkatov AN, Simonenko GV, Odoevskaya OD, Tuchin VV, Altshuler GB: Low-intensity indocyanine-green laser phototherapy of acne vulgaris: pilot study. J Biomed Opt 2004, 9:828-834.

25. Nouri K, Ballard CJ: Laser therapy for acne. Clin Dermatol 2006, 24:26-32.

26. Saxena V, Sadoqi M, Shao J: Indocyanine green-loaded biodegradable nanoparticles: preparation, physicochemical characterization and in vitro release. Int J Pharm 2004, 278:293-30 I.

27. Malicka J, Gryczynski I, Geddes CD, Lakowicz JR: Metal-enhanced emission from indocyanine green: a new approach to in vivo imaging. J Biomed Opt 2003, 8:472-478.

28. Tseng WW, Saxton RE, Deganutti A, Liu CD: Infrared laser activation of indocyanine green inhibits growth in human pancreatic cancer. Pancreas 2003, 27:e42-e45.

29. Baumler W, Abels C, Karrer S, Weiss T, Messmann H, Landthaler M, Szeimies RM: Photo-oxidative killing of human colonic cancer cells using indocyanine green and infrared light. $\mathrm{Br} J$ Cancer 1999, 80:360-3. 
30. Urbanska K, Romanowska-Dixon B, Matuszak Z, Oszajca J, NowakSliwinsk P, Stochel G: Indocyanine green as a prospective sensitizer for photodynamic therapy of melanomas. Acta Biochim Pol 2002, 49:387-39l.

31. Iriyama A, Uchida S, Yanagi Y, Tamaki Y, Inoue Y, Matsuura K, Kadonosono $K$, Araie $M$ : Effects of indocyanine green on retinal ganglion cells. Invest Ophthalmol Vis Sci 2004, 45:943-947.

32. Jackson TL, Hillenkamp J, Knight BC, Zhang JJ, Thomas D, Stanford $M R$, Marshall J: Safety testing of indocyanine green and trypan blue using retinal pigment epithelium and glial cell cultures. Invest Ophthalmol Vis Sci 2004, 45:2778-2785.

33. Rezai KA, Farrokh-Siar L, Ernest JT, van Seventer GA: Indocyanine green induces apoptosis in human retinal pigment epithelial cells. Am J Ophthalmol 2004, I 37:931-933.

34. Skrivanova K, Skorpikova J, Svihalek J, Mornstein V, Janisch R: Photochemical properties of a potential photosensitiser indocyanine green in vitro. J Photochem Photobiol B 2006, 85: I50-I54.

35. Czajka MP, McCuen BW, Cummings TJ, Nguyen H, Stinnett S, Wong $\mathrm{F}$ : Effects of indocyanine green on the retina and retinal pigment epithelium in a porcine model of retinal hole. Retine 2004, 24:275-282.

36. Yip HK, Lai TY, So KF, Kwok AK: Retinal ganglion cells toxicity caused by photosensitising effects of intravitreal indocyanine green with illumination in rat eyes. $\mathrm{Br} J$ Ophthalmol 2006, 90:99-102.

37. Saikia P, Maisch T, Kobuch K, Jackson TL, Baumler W, Szeimies RM, Gabel VP, Hillenkamp J: Safety testing of indocyanine green in an ex vivo porcine retina model. Invest Ophthalmol Vis Sci 2006, 47:4998-5003.

38. Abels C, Fickweiler S, Weiderer P, Bäumler W, Hofstädter F, Landthaler M, Szeimies RM: Indocyanine green (ICG) and laser irradiation induce photooxidation. Arch Dermatol Res 2000, 292:404-4II.

39. Maisch T, Szeimies RM, Jori G, Abels C: Antibacterial photodynamic therapy in dermatology. Photochem Photobiol Sci 2004, 3:907-917.

40. Jori G, Brown SB: Photosensitized inactivation of microorganisms. Photochem Photobiol Sci 2004, 3:403-405.

41. Malik Z, Ladan H, Nitzan : Photodynamic inactivation of Gram negative bacteria: problems and possible solutions. I Photochem Photobiol B: Biol 1990, 5:281-293.

42. Nussbaum EL, Lilge L, Mazzulli T: Effects of low-level laser therapy (LLLT) of $810 \mathrm{~nm}$ upon in vitro growth of bacteria: relevance of irradiance and radiant exposure. J Clin Laser Med Surg 2003, $21: 283-290$

43. Nitzan Y, Balzam-Sudakevitz A, Ashkenazi H: Eradication of Acinetobacter baumannii by photosensitized agents in vitro. I Photochem Photobiol B 1998, 42:21 I-218.

44. Lu WD, Atkins WM: A novel antioxidant role for ligandin behavior of glutathione S-transferases: attenuation of the photodynamic effects of hypericin. Biochemistry 2004, 43:|276|-|2769.

45. Lambrechts SA, Aalders MC, Verbraak FD, Lagerberg JW, Dankert JB, Schuitmaker J]: Effect of albumin on the photodynamic inactivation of microorganisms by a cationic porphyrin. J Photochem Photobiol B 2005, 79:5।-57.

46. Matheson IB, Etheridge RD, Kratowich NR, Lee J: The quenching of singlet oxygen by amino acids and proteins. Photochem Photobiol |975, 21:|65-|7|.

47. Storm FK, Harrison WH, Elliott RS, Morton DL: Normal tissue and solid tumor effects of hyperthermia in animal models and clinical trials. Cancer Res 1979, 39:2245-225I.

48. Prins JB, Walker NI, Winterford CM, Cameron DP: Apoptosis of human adipocytes in vitro. Biochem Biophys Res Commun 1994, 201:500-507.

49. Henderson BW, Waldow SM, Potter WR, Dougherty TJ: Interaction of photodynamic therapy and hyperthermia: tumor response and cell survival studies after treatment of mice in vivo. Cancer Res 1985, 45:6071-6077.

50. Altshuler GB, Zenzie HH, Erofeev AV, Smirnov MZ, Anderson RR, Dierickx C: Contact cooling of the skin. Phys Med Biol 1999, 44:1003-1023.

51. Clayton TH, Harrison PV: Photodynamic therapy for infected leg ulcers. Br J Dermatol 2007, I 56:384-385.

52. Carvalho Pde T, Marques AP, Reis FA, Belchior AC, Silva IS, Habitante $C A$, Sussai DA: Photodynamic inactivation of in vitro bacterial cultures from pressure ulcers. Acta Cir Bras 2006, 2I(Suppl 4):32-35.

53. Chin WW, Heng PW, Bhuvaneswari R, Lau WK, Olivo M: The potential application of chlorin e6-polyvinylpyrrolidone formulation in photodynamic therapy. Photochem Photobiol Sci 2006, 5:1031-1037.

54. Maisch T: Anti-microbial photodynamic therapy: useful in the future? Lasers Med Sci 2006.

55. Allison RR, Downie GH, Cuenca R, Hu XH, Childs CJ, Sibata $\mathrm{CH}$ Photosensitizers in clinical PDT. Photodiag Photodyn Ther 2004, I :27-42.

56. Detty MR, Gibson SL, Wagner SJ: Current clinical and preclinica photosensitizers for use in photodynamic therapy. J Med Chem 2004, 47:3897-3915.

Publish with Bio Med Central and every scientist can read your work free of charge

"BioMed Central will be the most significant development for disseminating the results of biomedical research in our lifetime. "

Sir Paul Nurse, Cancer Research UK

Your research papers will be:

- available free of charge to the entire biomedical community

- peer reviewed and published immediately upon acceptance

- cited in PubMed and archived on PubMed Central

- yours - you keep the copyright
BioMedcentral 